\title{
Anatomia da diferença: uma investigação teórico-descritiva da deficiência à luz do cotidiano
}

\author{
Anatomy of difference: a theoretical and descriptive investigation \\ into handicaps from an everyday perspective
}

\author{
Ray Pereira \\ Tese de doutoramento \\ Escola Nacional de Saúde Pública Sérgio Arouca (ENSP)/Fundação Oswaldo Cruz \\ Rio de Janeiro, 2006 \\ raypereira@uol.com.br
}

\begin{abstract}
A pesquisa em pauta, desenvolvida como tese de doutorado em Saúde Pública, teoriza sobre a deficiência tendo como foco a condição de 'diferente', 'anormal' ou 'desviante' atribuída à pessoa com deficiência. Sendo a diferença estampada na deficiência o elemento norteador da pesquisa, optou-se por não segmentar a deficiência em suas várias formas ou graus de manifestação, tais como a física, sensorial, mental ou múltipla, mas sim por priorizar a condição de 'diferente' atribuída às pessoas que apresentam alguma deficiência. Para tanto, produziu-se um levantamento histórico-descritivo acerca das várias formas pelas quais a deficiência foi percebida e tratada desde a Antiguidade, bem como a influência desse histórico no convívio social com a 'diferença'. Foram analisados criticamente alguns modelos teóricos que tentam explicar a deficiência, como o modelo religioso, o médico e o sociocultural, destacando-se suas influências na concepção atual, no trato com as pessoas com deficiência e na vivência cotidiana destas em busca de espaço nos vários segmentos sociais. Investigaram-se produções teóricas acerca do tema, provenientes de diversas áreas do conhecimento, como psicologia, história, sociologia e medicina, inclusive a produção de autores que vivenciam a deficiência. A pesquisa contempla a questão da conceituação da deficiência, analisando o seu desenvolvimento e a construção da terminologia vigente. Discute questões afins, tais como identidade, alteridade, diferença e normalidade, além de temas atuais como a ciborguização e a utilização de células-tronco, sob a ótica do cotidiano da deficiência, incluindo-se aspectos da experiência vivencial com a deficiência. Confirma que a deficiência é uma condição socialmente discriminada, tendo variado, desde a Antiguidade, a forma como cada grupo social ou cada época discrimina a pessoa com deficiência. Atualmente, apesar do discurso e das práticas denominados 'inclusivos', a deficiência continua sujeita à discriminação e segregação social, o que dificulta a obtenção de oportunidades educacionais, profissionais e sociais, condições para uma cidadania plena. A pesquisa assinala a diferença como característica norteadora, a matéria-prima com a qual se construiu a deficiência. Os avanços tecnológicos indicam que a deficiência, como disfunção, poderá ser futuramente extinta, mas a diferença, por ser inerente à condição humana, será mantida, podendo, dessa maneira, produzir novas formas de deficiência e, conseqüentemente, novas manifestações de preconceito e segregação social.
\end{abstract}

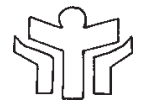

